\title{
DISCUSSION
}

\section{Discussion of the origin of 'arrested' charnockitization in the Chilka Lake area, Eastern Ghats Belt, India}

Keywords: Eastern Ghats; granulites; migmatization; charnockite; enderbite.

S. Bhattacharya \& S. K. Sen comment: In a recent paper, Dobmeier \& Raith (2000) have claimed to have provided 'conclusive evidence' that the patchy charnockites in the Chilka Lake area were formed from the leptynites which enclose them. This runs counter to our interpretation that these patches were derived from larger charnockitic layers through deformation and migmatization (Bhattacharya, Sen \& Acharyya, 1993). Any re-interpretation is in order, provided it does not ignore or distort the field facts. In our opinion, these authors have done so, and we are constrained to make the following points.

\section{Definition of charnockite and its use}

Dobmeier \& Raith (2000) refer to Streckeisen (1976) for definition and further alleged that improper use of the term charnockite 'allowed pooling of charnockite with enderbite, thereby leading to petrographic confusion and erroneous interpretations of charnockite formation' (p. 29).

(a) Charnockites and enderbites as defined in Streckeisen (1976) occur together, along with intermediate varieties, in many granulite terranes which contain these rocks (Newton, 1992). It may be recalled that in the Streckeisen system of nomenclature charnockites have alkali feldspar:plagioclase proportions varying from 90:10 to $35: 65$; while in enderbites they vary from $10: 90$ to $0: 100$. Rocks with alkali feldspar:plagioclase ratios falling in between are styled charno-enderbites.

(b) In the Chilka area many larger bands which have all been labelled as enderbites by Dobmeier \& Raith (2000) are charnockites according to this definition. In the five sets of modal analyses reported in Bhattacharya, Sen \& Acharyya (1993) three are distinctly charnockites in the cores, their relative alkali feldspar:plagioclase proportions being 16:20, $18: 20$ and 14:18. Among the other two, one with the ratio $16: 25$ is practically a charno-enderbite, while the other with 32:7 is an alkali feldspar charnockite. Thus Dobmeier \& Raith's generalization that all larger bands are enderbites is incorrect.

(c) The most significant aspect of the modal data from cores, margins and detached patches of charnockites as given in table 2 of Bhattacharya, Sen \& Acharyya (1993) is the variation of alkali feldspar:plagioclase ratios from cores to margins, and detached patches, as for example, in HM-1, from 14:18 (A) through 17:16 (B) to 21:9(D).

Thus on the one hand, Dobmeier \& Raith overlooked the internal petrographic variations of the large bands; on the other, they missed the important fact that many larger bands are not enderbitic, but charnockitic. Their argument that the centimetre- to decimetre-scale patches never contain any enderbite core is not a significant one because of the scale.

\section{Leptynite-charnockite field association and chemistry}

Dobmeier \& Raith (2000) imply that the occurrence of small patches of charnockites ('arrested type charnockite domains') exclusively within leptynites (p. 34) indicates a genetic connection between the two; and 'in situ formation of the charnockite domains within the leptynite bands is evident from their restricted mode of occurrence' (p. 35).

First, this is neither a necessary nor a sufficient condition; second, presence of inclusions of pre-existing rocks within granites in deformed and migmatized terranes, as pictured in our model, is not incompatible with such field associations.

The chemical analysis of charnockite in table 1 of their paper is not convincing. A representative modal analysis given by these authors has $8 \%$ orthopyroxene by volume; according to our experience 8 to $10 \%$ orthopyroxene is quite common in these charnockites.

We have analysed several orthopyroxene grains from the patchy charnockites of this area (Sen, Bhattacharya \& Acharyya, 1995). The $\mathrm{MgO}$ contents of these orthopyroxenes vary from 9.8 to $14.2 \%$ approximately. A rough calculation shows that $8 \%$ by volume of orthopyroxene (corresponding to $10 \%$ by weight) with an average of $12 \%$ $\mathrm{MgO}$ will result in $1.2 \% \mathrm{MgO}$ in the rock. Even if we assume that the rock sample for analysis did not contain garnet or biotite, $0.49 \% \mathrm{MgO}$ reported by Dobmeier \& Raith (2000) turns out to be less than half of this amount. The modal and chemical data are apparently incompatible, and there is a distinct possibility that the selected rock sample had a sizeable component of leptynite or leucogranite.

\section{Dobmeier \& Raith's suggested transformation reaction (p. 35) and possible petrographic evidence}

Leptynites in this area, based on our extensive petrographic survey, have very small amounts of biotite (normally between 1 and $4 \%$ ) and the biotite grains, by and large, are secondary (for compositionally different primary biotites, which are rare, see Sen $\&$ Bhattacharya, 1997). These render the transformation reaction $\mathrm{Bt}+\mathrm{Grt}+\mathrm{Fl}_{1} \leftrightarrow \mathrm{Opx}+\mathrm{Fsp}+\mathrm{Ilm}+\mathrm{Fl}_{2} / \mathrm{L}$, suggested by Dobmeier \& Raith, questionable from the viewpoint of both petrographic match and time.

Even if it is assumed that there were primary biotites in leptynites that have reacted out, problems remain. In the absence of stoichiometric coefficients we can treat the above reaction as a combination of two reactions:

$\mathrm{Bt}+3 \mathrm{Qtz}=\mathrm{Ksp}+3 \mathrm{Opx}+$ Fluid

$\mathrm{Grt}\left(\frac{1}{3} \mathrm{Gr}+\frac{2}{3} \mathrm{Alm}-\mathrm{Py}\right)+\mathrm{Qtz}=2 \mathrm{Opx}+\mathrm{An}$

Computations using the molecular volume of Mg-endmembers show that to produce $100 \mathrm{~cm}^{3}$ of charnockite with 8 
vol. $\%$ of orthopyroxene by reaction (1), $13.3 \mathrm{~cm}^{3}$ of biotite is required. If the leptynites contained $3 \%$ by volume of primary biotite, then $443 \mathrm{~cm}^{3}$ of rock will be depleted in biotite for every $100 \mathrm{~cm}^{3}$ of charnockite produced (these calculations ignore the volume change of reactions, which should have a rather insignificant effect). Considering reactions (1) and (2) together, and assuming that equal amounts of biotite and garnet were involved in the reaction, every cubic centimetre of orthopyroxene produced would require roughly $0.9 \mathrm{~cm}^{3}$ of biotite, thus reducing the volume of rock depleted in biotite to $250 \mathrm{~cm}^{3}$ per $100 \mathrm{~cm}^{3}$ of charnockite produced.

These calculations are simplified, but they make the point that in order to validate the reaction suggested by Dobmeier \& Raith (2000), the reactants will have to be extracted from a larger area, showing depletion in garnet and biotite. Our petrographic survey does not indicate the presence of such depleted zones around the charnockite patches.

\section{Proposed structural-microstructural evidence for synkinematic growth (p. 35)}

The structural evidence, such as preferred orientation of orthopyroxene crystals in the patchy charnockites, does not preclude our hypothesis of remnant origin (Bhattacharya, Sen \& Acharyya, 1993). Dobmeier \& Raith emphasized the difference in signatures of deformation in large enderbite layers and small patchy charnockites. Both domains show orthopyroxenes with preferred orientation, but intracrystalline deformation is absent in the orthopyroxenes of the charnockite domains. In migmatites it is not uncommon to find older (melanosome) grains showing preferred orientation, due to rotational deformation, when migmatization is syntectonic. Thus larger bodies/layers of enderbite may preserve intracrystalline deformation, while smaller patches, caught up in the partial melt (leptynite), could suffer rigid body rotation without showing signs of intracrystalline deformation. Here we would like to emphasize two points: (a) anatectic migmatite was largely melt-dominated, and (b) migmatization was syntectonic. Ashworth \& McLellan (1985) stated 'In the Mid-Strathspey specimen of Ashworth (1979), where structural control of segregation indicates that migmatization was syntectonic, there is some biotite fabric (girdle of (001) poles, due to rotational deformation) and a quartz shape fabric; if an anatectic origin is accepted, then the deformation must have outlasted the crystallization of the melt'. Hence it is not necessary that relic orthopyroxenes showing preferred orientation must also show signs of intracrystalline deformation.

As a matter of fact, some of the observations of Dobmeier \& Raith (2000) are better explained in our model. For example, Dobmeier \& Raith (2000) noted that in weakly deformed enderbite layers orthopyroxenes preserve a fabric related to $\mathrm{L}_{2}$ and $\mathrm{S}_{2}$, while in strongly deformed thin enderbite layers, close to areas of charnockite formation, the orthopyroxene orientation pattern is similar to that in charnockite domains (p. 35).

\section{Field relation between larger bands and smaller patches of charnockites}

In the Chilka Lake area, many of the centimetre- to decimetre-scale patches are demonstrably dismembered, by deformation, from adjoining larger bands and layers (fig. 5 in Bhattacharya, Sen \& Acharyya, 1993). Dobmeier \& Raith have completely overlooked this significant field feature.
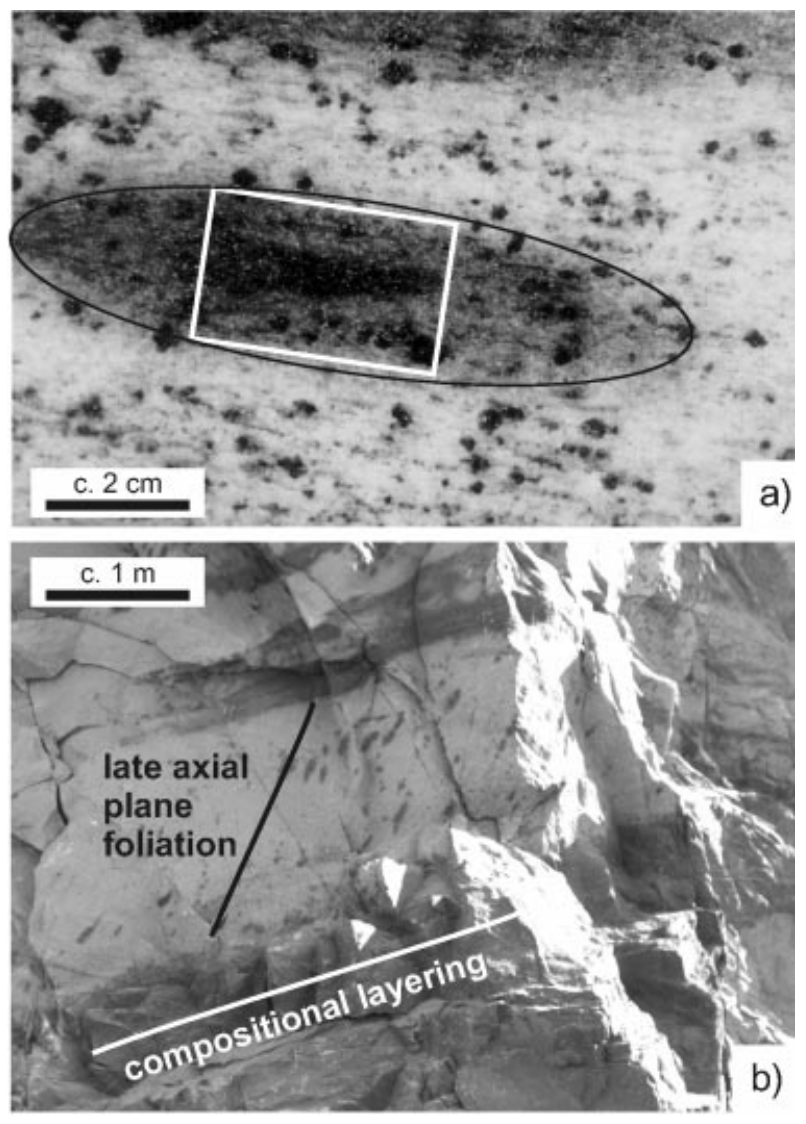

Figure 1. (a) Photograph of an arrested-type charnockite domain (corresponds with fig. 2c in Dobmeier \& Raith, 2000). The box indicates the thin section area for which the earlier published mode applies. The ellipsoid encloses the area used for the chemical bulk rock analysis published in Dobmeier \& Raith (2000). (b) Several arrays of arrestedtype charnockite domains are aligned along the axial planar foliation of late folds and at high angle to the folded compositional layering.

The origin of charnockites in a complex high-grade area is not easy to unravel and may be amenable to different interpretations. But one wonders how seriously the claim of providing 'conclusive evidence' should be taken when many field and petrographic facts are ignored and lines of evidence stretched (as in the case with chemistry of charnockites).

C. Dobmeier \& M. M. Raith reply: In our publication 'On the origin of 'arrested' charnockitization in the Chilka Lake area, Eastern Ghats Belt, India: a reappraisal' (Dobmeier \& Raith, 2000) we have carefully laid out our understanding of arrested-type charnockite formation in two clearly identified localities near Khurda. Our model is based on our own field observations and analytical data. Further, we have presented the first modern analysis of the regional deformation inclusive of kinematic indicators. In principle, we have nothing to add to our model, but the comments of Bhattacharya \& Sen make it necessary to lay out in more detail certain aspects of our model in order to adjust their rather sophistic reasoning. We reply to their points as follows:

1. Our published modal and chemical bulk rock compositions unambiguously demonstrate that all mafic layers that border leptynite layers containing arrested-type charnockite domains in the quarries Hatia and Calcutta are enderbitic, i.e. enderbite or mafic charno-enderbite. Charnockitic layers 
Table 1. Representative microprobe analyses of biotite, garnet, and orthopyroxene from leptynite and arrested-type charnockite of the Hatia quarry

\begin{tabular}{|c|c|c|c|c|c|c|c|c|c|c|c|c|}
\hline \multirow{3}{*}{$\begin{array}{l}\text { Sample } \\
\text { Analysis }\end{array}$} & \multicolumn{5}{|c|}{ Garnet } & \multicolumn{4}{|c|}{ Biotite } & \multirow{2}{*}{\multicolumn{3}{|c|}{$\begin{array}{c}\text { Orthopyroxene } \\
\text { Charnockite CH-5 }\end{array}$}} \\
\hline & \multicolumn{2}{|c|}{ Leptynite CH-5 } & \multicolumn{3}{|c|}{ Charnockite $\mathrm{CH}-5$} & \multicolumn{2}{|c|}{ Leptynite $\mathrm{CH}-5$} & \multicolumn{2}{|c|}{ Charnockite CH-5 } & & & \\
\hline & 1-core & 8-rim & 14-core & 26/opx & $44 / \mathrm{bt}$ & 16-core & $14 /$ grt & 4-core & 21/opx & 12-core & $15 /$ grt & $38 / \mathrm{bt}$ \\
\hline $\mathrm{SiO}_{2}$ & 37.03 & 37.07 & 36.93 & 37.11 & 37.11 & 36.34 & 36.91 & 37.17 & 36.67 & 48.31 & 47.62 & 48.49 \\
\hline $\mathrm{TiO}_{2}^{2}$ & 0.05 & 0.03 & 0.00 & 0.03 & 0.09 & 5.62 & 4.62 & 4.08 & 3.99 & 0.05 & 0.09 & 0.12 \\
\hline $\mathrm{Al}_{2} \mathrm{O}_{3}^{2}$ & 20.84 & 20.59 & 20.66 & 20.67 & 20.82 & 13.16 & 13.18 & 13.48 & 13.09 & 1.22 & 1.02 & 1.33 \\
\hline $\mathrm{Cr}_{2}^{2} \mathrm{O}_{3}^{3}$ & 0.00 & 0.00 & 0.00 & 0.00 & 0.00 & 0.01 & 0.02 & 0.01 & 0.03 & 0.00 & 0.00 & 0.01 \\
\hline $\mathrm{FeO}^{3}$ & 32.69 & 33.63 & 34.64 & 33.46 & 34.50 & 22.76 & 20.42 & 21.55 & 22.44 & 39.56 & 40.44 & 39.48 \\
\hline $\mathrm{MnO}$ & 0.92 & 0.81 & 0.71 & 0.70 & 1.24 & 0.01 & 0.06 & 0.03 & 0.04 & 0.25 & 0.26 & 0.18 \\
\hline $\mathrm{MgO}$ & 2.79 & 2.66 & 2.07 & 2.51 & 1.32 & 8.26 & 10.23 & 10.24 & 9.24 & 9.72 & 9.17 & 9.42 \\
\hline $\mathrm{CaO}$ & 4.83 & 4.68 & 4.73 & 4.73 & 4.70 & 0.00 & 0.03 & 0.00 & 0.03 & 0.42 & 0.41 & 0.62 \\
\hline $\mathrm{Na}_{2} \mathrm{O}$ & - & - & - & - & - & 0.04 & 0.04 & 0.05 & 0.04 & 0.34 & 0.46 & 0.02 \\
\hline $\mathrm{K}_{2} \mathrm{O}$ & - & - & - & - & - & 9.42 & 9.69 & 9.98 & 9.77 & - & - & - \\
\hline $\mathrm{F}^{2}$ & - & - & - & - & - & 0.98 & 1.47 & 1.21 & 0.95 & - & - & - \\
\hline $\mathrm{OH}$ & - & - & - & - & - & 3.40 & 3.19 & 3.35 & 3.40 & - & - & - \\
\hline $\mathrm{F}=\mathrm{O}$ & - & - & - & - & - & -0.41 & -0.62 & -0.51 & -0.40 & - & - & - \\
\hline \multirow[t]{2}{*}{ Total } & 99.15 & 99.43 & 99.74 & 99.21 & 99.78 & 99.59 & 99.24 & 100.64 & 99.24 & 99.87 & 99.47 & 99.67 \\
\hline & \multicolumn{5}{|c|}{ Formulae based on 24 oxygens } & \multicolumn{4}{|c|}{ Formulae based on $24(\mathrm{O}, \mathrm{OH}, \mathrm{F})$} & \multicolumn{3}{|c|}{$\begin{array}{c}\text { Formulae based on } \\
6 \text { oxygens }\end{array}$} \\
\hline $\mathrm{Si}$ & 5.99 & 5.99 & 5.99 & 6.01 & 6.00 & 2.82 & 2.85 & 2.84 & 2.85 & 1.97 & 1.96 & 1.97 \\
\hline $\mathrm{Al}{ }^{\mathrm{IV}}$ & - & - & - & - & - & 1.18 & 1.15 & 1.16 & 1.15 & - & - & - \\
\hline $\mathrm{Al}^{\mathrm{VI}}$ & 3.97 & 3.92 & 3.94 & 3.94 & 3.98 & 0.02 & 0.05 & 0.04 & 0.05 & 0.06 & 0.05 & 0.06 \\
\hline $\mathrm{Ti}$ & 0.01 & 0.00 & 0.00 & 0.00 & 0.01 & 0.33 & 0.27 & 0.23 & 0.23 & 0.00 & 0.00 & 0.00 \\
\hline $\mathrm{Cr}$ & 0.00 & 0.00 & 0.00 & 0.00 & 0.00 & 0.00 & 0.00 & 0.00 & 0.00 & 0.00 & 0.00 & 0.00 \\
\hline $\mathrm{Fe}^{2+}$ & 4.42 & 4.55 & 4.69 & 4.53 & 4.67 & 1.48 & 1.32 & 1.38 & 1.46 & 1.35 & 1.39 & 1.34 \\
\hline $\mathrm{Mn}$ & 0.13 & 0.11 & 0.10 & 0.10 & 0.17 & 0.00 & 0.00 & 0.00 & 0.00 & 0.01 & 0.01 & 0.01 \\
\hline $\mathrm{Mg}$ & 0.67 & 0.64 & 0.50 & 0.61 & 0.32 & 0.96 & 1.18 & 1.17 & 1.07 & 0.59 & 0.56 & 0.57 \\
\hline $\mathrm{Ca}$ & 0.84 & 0.81 & 0.82 & 0.82 & 0.82 & 0.00 & 0.00 & 0.00 & 0.00 & 0.02 & 0.02 & 0.03 \\
\hline $\mathrm{Na}$ & - & - & - & - & - & 0.01 & 0.01 & 0.01 & 0.01 & 0.03 & 0.04 & 0.00 \\
\hline $\mathrm{K}$ & - & - & - & - & - & 0.93 & 0.95 & 0.97 & 0.97 & - & - & - \\
\hline $\mathrm{F}$ & - & - & - & - & - & 0.24 & 0.36 & 0.29 & 0.24 & - & - & - \\
\hline $\mathrm{OH}$ & - & - & - & - & - & 1.76 & 1.64 & 1.71 & 1.77 & - & - & - \\
\hline $\mathrm{X}_{\mathrm{Mg}}$ & - & - & - & - & - & 0.39 & 0.47 & 0.46 & 0.42 & 0.30 & 0.29 & 0.30 \\
\hline $\mathrm{X}_{\mathrm{F}}^{\mathrm{Mg}}$ & - & - & - & - & - & 0.12 & 0.18 & 0.15 & 0.12 & - & - & - \\
\hline Alm & 73.0 & 74.5 & 76.8 & 74.9 & 78.3 & - & - & - & - & - & - & - \\
\hline Pyr & 11.1 & 10.5 & 8.2 & 10.0 & 5.3 & - & - & - & - & - & - & - \\
\hline Grs & 13.8 & 13.2 & 13.4 & 13.5 & 13.5 & - & - & - & - & - & - & - \\
\hline Sps & 2.1 & .8 & 1.6 & 1.6 & 2.9 & - & - & - & - & - & - & - \\
\hline
\end{tabular}

may occur in the wider Chilka Lake area, but these layers bear no relation to arrested-type charnockite formation. In this context we emphasize that we have determined all modes on stained thin sections.

2. The combination of mineral chemical analyses from one set of samples with bulk rock chemical analyses of a different set of samples is inadmissible. In order to facilitate accurate comparison of mineral and bulk rock chemical analyses, and proper reintegration of mineral chemical data and mode, we introduce own mineral chemical analyses (Table 1), which were not published in Dobmeier \& Raith (2000) on editorial advice. Effectively, the $\mathrm{MgO}$ content in orthopyroxene from arrested-type charnockite domains varies only slightly between 9.17 and $9.72 \mathrm{wt} \%$. Reintegration of the most magnesian composition with the modal amount of orthopyroxene yields a $\mathrm{MgO}$ estimate of $0.78 \mathrm{wt} \%$ for the bulk rock.

The remaining discrepancy arises from the fact that the published mode is valid only for the central orthopyroxenebearing area of the arrested-type charnockite domain (Fig. 1a). Here we have to correct our published mode. Taking into account that the not considered area of the arrestedtype charnockite domain contains no orthopyroxene, and adjusting for the three-dimensional shape of the domain (ellipsoid with axial ratio $x: y: z \approx 4: 2: 1$ ), the orthopyroxene content is reduced to $4-5$ vol. $\%$. Only this recalculation allows direct comparison of mode and chemical bulk rock composition, as the latter was determined for the entire charnockite domain (= coloured area). The calculated $\mathrm{MgO}$ content of less than $0.5 \mathrm{wt} \%$ for the bulk rock composition is in perfect agreement with our published chemical analysis.

3 . The regular distribution of biotite and its strong preferred orientation (basal $c$-plane parallel to the pervasive foliation) evidences that biotite in leptynite is not of secondary origin. This is corroborated by chemical compositions which are typical for granulite facies biotites (e.g. high Ti contents of 3.5-6.0 wt\% (Sen \& Bhattacharya, 1997); 4-5.6 wt \%, own data given in Table 1). The formation of secondary biotite by destabilization of hypersthene and garnet has been observed very rarely in fresh samples.

The volumetric calculations of Bhattacharya \& Sen are incorrect. Considering equal $\mathrm{MgO}$ contents in biotite and orthopyroxene (Table 1), and equal modal amounts of biotite in leptynite and orthopyroxene in charnockite, the apparent discrepancy is resolved. Readjustment for the lower density of biotite $\left(\sim 3.1 \mathrm{~g} \mathrm{~cm}^{-3}\right.$, orthopyroxene $\sim 3.7 \mathrm{~g} \mathrm{~cm}^{-3}$; both given at $0.1 \mathrm{MPa}, 298 \mathrm{~K}$ ) does not alter the situation in the presence of sufficient garnet. 
4. Bhattacharya \& Sen's notion of rigid body rotation in a migmatite does not apply, simply as migmatites do not occur in the studied quarries. Field relations show that leuco-granite, which was later transformed into leptynite, is intrusive into the enderbitic rocks. The emplacement occurred probably at $\sim 750 \mathrm{Ma}$, and was followed by an intense transpressional deformation at $690-660 \mathrm{Ma}$ (Dobmeier \& Simmat, 2002).

The vague statement of Bhattacharya $\&$ Sen on the origin of the arrested-type charnockite domains faces the following problems:

(i) If the arrested-type charnockite domains are interpreted as boudins, it has to be explained, why only charnockite layers have been boudinaged whereas enderbite layers and septs remained intact (see fig. 2a in Dobmeier \& Raith, 2000; Fig. 1b). Boudinage requires high competence contrasts between adjacent lithologies. But the competence contrast between charnockite and leptynite is negligible whereas the competence contrast between enderbite and leptynite is high.

(ii) If the arrested-type charnockite domains are interpreted as xenoliths, the absence of enderbitic xenoliths has to be convincingly explained.

(iii) The following micro- and macroscopic observations are not compatible with the assumed boudin or xenolith nature of the arrested-type charnockite domains. Chemical mineral compositions and microfabrics of feldspars and quartz in arrested-type charnockite domains and leptynite are identical, and no lithological boundary can be defined in thin section. The only difference between the two lithologies is the growth of orthopyroxene at the expense of biotite and garnet in the cores of the charnockite domains. Polygranular quartz ribbons do not end at the diffuse macroscopic boundary but continue well into the charnockite domains.

Further, Bhattacharya \& Sen misunderstood the significance of our published orthopyroxene $c$-axis patterns. Both patterns from enderbite samples show two $c$-axis maxima, one subparallel and one subperpendicular to the stretching lineation. For elongate orthorhombic minerals like orthopyroxene, such bipolar patterns typically indicate the reorientation of pre-existing grains during deformation, as the two maxima coincide with the two mechanically most stable positions of the elongate grains during rotational deformation. The unipolar orthopyroxene $c$-axis pattern of the charnockite sample would require a high degree of predeformational preferred orientation, which has not been observed in the assumed parental rocks. The interpretation as primary growth pattern is much more convincing.

5 . We have never questioned the presence of narrow septs, which formed during the leucogranite intrusion. However, we have never observed boudinage of enderbitic septs (see fig. 2a in Dobmeier \& Raith, 2000; Fig. 1b), and we feel that the sketchy line drawing (fig. 5) in Bhattacharya, Sen \& Acharyya (1993) is hardly suitable as proof for the boudinage of enderbitic layers.

Figure 1b clearly shows that arrays of arrested-type charnockite domains are oriented at high angle to the com- positional layering, and parallel to the axial planar foliation of late upright folds. This distinct mode of occurrence effectively excludes the existence of arrested-type charnockite domains prior to the late folding event.

In light of our detailed reply, the last paragraph of Bhattacharya \& Sen's discussion does not require any comment.

Acknowledgements. Bhattacharya \& Sen thank E. Hansen and H. Rollinson for their helpful suggestions on an earlier version of the Comment.

\section{References}

Ashworth, J. R. 1979. Comparative petrography of deformed and undeformed migmatites from the Grampian Highlands of Scotland. Geological Magazine 116, 445-56.

Ashworth, J. R \& McLellan, E. L. 1985. Textures. In Migmatites (ed. J. R. Ashworth), pp. 180-203. Glasgow: Blackie, 302 pp.

Bhattacharya, S., Sen, S. K. \& Acharyya, A. 1993. Structural evidence supporting a remnant origin patchy charnockites in the Chilka Lake area, India. Geological Magazine 130, 363-8.

Dobmeier, C. \& RAith, M. 2000. On the origin of 'arrested' charnockitization in the Chilka Lake area, Eastern Ghats Belt, India: a reappraisal. Geological Magazine $137,27-37$.

Dobmeier, C. \& Simmat, R. 2002. Post-Grenvillian transpression in the Chilka Lake area, Eastern Ghats Belt implications for the geological evolution of peninsular India. Precambrian Research 113, 243-68.

Newton, R. C. 1992. An overview of charnockite. Precambrian Research 55, 399-405

Sen, S. K. \& Bhattacharya, S. 1997. Dehydration melting of micas in the Chilka Lake khondalites: the link between the metapelites and granitoids. Proceedings of Indian Academy of Sciences 106, 277-97.

Sen, S. K., Bhattacharya, S. \& Acharyya, A. 1995. A multi-stage pressure-temperature record in the Chilka Lake granulites: the epitome of the metamorphic evolution of Eastern Ghats, India? Journal of Metamorphic Geology 13, 287-98.

Streckeisen, A. 1976. To each plutonic rock its proper name. Earth Science Reviews 12, 1-33.

S. Bhattacharya, Geological Studies Unit, Indian Statistical Institute, 203 BT Road, Calcutta 700035, India; email: samar@isical.ac.in

S. K. SEN, Department of Geological Sciences, Jadavpur University, Calcutta 700032, India

C. Dobmeier, Institut für Geologische Wissenschaften, Fachrichtung Geologie, Freie Universität Berlin, Malteserstraße 74-100, D-12249 Berlin, Germany; email: dobmeier@zedat.fu-berlin.de

M. M. RAITH, Mineralogisch-Petrologisches Institut, Universität Bonn, Poppelsdorfer Schloss, D-53115 Bonn, Germany 